$10-2018$

\title{
Restoring the eastern oyster: how much progress has been made in 53 years?
}

\author{
AB Hernandez \\ RD Brumbaugh \\ P Fredrick \\ R Grizzle \\ Mark Luckenbach \\ Virginia Institute of Marine Science
}

See next page for additional authors

Follow this and additional works at: https://scholarworks.wm.edu/vimsarticles

Part of the Aquaculture and Fisheries Commons, Environmental Sciences Commons, and the Marine Biology Commons

\section{Recommended Citation}

Hernandez, AB; Brumbaugh, RD; Fredrick, P; Grizzle, R; Luckenbach, Mark; Peterson, CH; and Angelini, C, Restoring the eastern oyster: how much progress has been made in 53 years? (2018). Frontiers in Ecology and the Environment, 16(8), 463-471.

10.1002/fee.1935

This Article is brought to you for free and open access by the Virginia Institute of Marine Science at W\&M ScholarWorks. It has been accepted for inclusion in VIMS Articles by an authorized administrator of W\&M ScholarWorks. For more information, please contact scholarworks@wm.edu. 
Authors

AB Hernandez, RD Brumbaugh, P Fredrick, R Grizzle, Mark Luckenbach, CH Peterson, and C Angelini 


\title{
Restoring the eastern oyster: how much progress has been made in 53 years?
}

\author{
Ada Bersoza Hernández ${ }^{1 \star}$, Robert D Brumbaugh ${ }^{2}$, Peter Frederick ${ }^{3}$, Raymond Grizzle ${ }^{4}$, Mark W Luckenbach ${ }^{5}$, Charles H \\ Peterson $^{6}$, and Christine Angelini ${ }^{1}$
}

Coastal ecosystem restoration is accelerating globally as a means of enhancing shoreline protection, carbon storage, water quality, fisheries, and biodiversity. Among the most substantial of these efforts have been those focused on re-establishing oyster reefs across the US Atlantic and Gulf coasts. Despite considerable investment, it is unclear how the scale of and approaches toward oyster restoration have evolved. A synthesis of 1768 projects undertaken since 1964 reveals that oyster substrate restoration efforts have primarily been concentrated in the Chesapeake Bay and the Gulf Coast, have been heavily reliant on oyster shell, and have re-established $4.5 \%$ of the reef area that has been lost across all regions. By comparing costs to ecosystem service benefits, we discovered that the return-on-investment of oyster restoration varies widely, but generally increases with project size. To facilitate the recovery of coastal ecosystems and their services, scientists and resource managers must adopt a new restoration paradigm prioritizing investment in sites that maximize economic and ecological benefits and minimize construction costs.

Front Ecol Environ 2018; 16(8): 463-471, doi: 10.1002/fee.1935

Cor centuries, productive fisheries, sheltered waterways, and a variety of other goods and services have drawn humans to settle near coastal areas (Worm et al.2006), but development has been so intensive that no coastal habitats - including marshes, seagrass meadows, forests, and reefs - remain immune to human impact (Halpern et al. 2008). With over one-third of the global population residing within $100 \mathrm{~km}$ of a coastline,

\section{In a nutshell:}

- Restoration is perceived as essential for sustaining fisheries, biodiversity, and other ecosystem services in degraded coastal zones worldwide

- Efforts to restore oyster reefs are accelerating along the US Atlantic and Gulf coasts, but extensive areas must still be rehabilitated to recover historical oyster habitat baselines

- Investment in oyster restoration is more likely to be recouped via ecosystem service benefits when projects are large and in easy-to-access locations, as well as when inexpensive materials are used

- Larger funding streams in support of projects designed to produce specific outcomes and minimize implementation costs will increase the scale of oyster habitat rehabilitation and the likelihood of positive returns on investment

${ }^{1}$ Environmental Engineering Sciences, Engineering School of Sustainable Infrastructure and Environment, University of Florida, Gainesville, FL ${ }^{*}$ (acbersoza@ufl.edu); ${ }^{2}$ The Nature Conservancy, Coral Gables, FL; ${ }^{3}$ Department of Wildlife Ecology and Conservation, University of Florida, Gainesville, FL; ${ }^{4}$ Jackson Estuarine Laboratory, University of New Hampshire, Durham, NH; ${ }^{5}$ Virginia Institute of Marine Science, College of William and Mary, Gloucester Point, VA; ${ }^{6}$ Institute of Marine Sciences, University of North Carolina at Chapel Hill, Morehead City, NC and 38 million people deriving employment from coastal fisheries and fish products (UNEP 2006; FAO 2014), continued reliance on these ecosystems is clear. However, centuries of human activity have led to widespread degradation of coastal ecosystems (Lotze et al.2006). Anthropogenic impacts, such as overexploitation, pollution, and eutrophication, have driven habitat and biodiversity losses, which, in turn, have compromised the ecosystem services received by coastal communities (Worm et al. 2006). If people are to sustainably interact with coastal ecosystems in the future, it is critical that the remaining natural ecosystems be protected and that degraded coastal habitats be restored.

Oyster reefs are among the most imperiled of the many threatened coastal habitats (Beck et al. 2011). Reef-building oysters have been harvested for centuries, for example by Imperial Romans in the 1st century CE (Kuijper and Turner 1992), Native Americans at least 3200 years ago (Rick et al. 2014), and European settlers in colonial America (Berry 2008). To meet growing demand, commercial harvesting of oysters began in the Middle Ages in Europe (Lotze et al. 2005) and in the early 1800s in the US (MacKenzie 1996), and intensified dramatically with the advent of dredging practices. Due to prolonged and intensive harvesting, the once-dominant species Crassostrea virginica, Ostrea lurida, and Ostrea conchaphila in North America (Kirby 2004; White et al. 2009); Ostrea edulis in Europe (Smyth et al. 2009); and Saccostrea glomerata in Australia (Kirby 2004) are now considered to be overexploited, and approximately $85 \%$ of oyster reefs have been lost worldwide (Beck et al 2011). Other stressors, such as disease, habitat destruction, and eutrophication, further limit oysters' persistence and recovery (Jackson 2008). This is of direct concern to humans, in part because of the economic value of oysters; oyster landings generate $\$ 190$ million (all dollar amounts are 
reported in US\$) in revenue annually in the US alone (NMFS 2015). Oysters also play an important ecological role as foundation species that protect shorelines, sequester carbon, enhance water quality, and support other fisheries by creating reef habitat (Grabowski et al. 2005; Coen et al. 2007).

Motivated by these economic and ecological values, interest in restoring oysters has grown (Coen et al. 2007). Numerous studies have evaluated the feasibility of restoring the European oyster (O edulis) in the UK (eg Laing et al. 2006; Alleway and Connell 2015), and although initial attempts to restock mudflats in the Wadden Sea with native oysters were unsuccessful and led to the introduction and subsequent invasion of the Pacific oyster (Crassostrea gigas; Diederich et al. 2005), efforts to restore native oysters in those waters have been renewed. Similarly, considerable effort has been made to rebuild Olympia oyster (O lurida) reefs in western US estuaries by planting oyster shell, as well as hatchery-produced spat-on-shell cultch (juvenile oysters attached to mollusk shell, coral, or similar material; Dinnel et al. 2009; McGraw 2009). However, no oyster species has been the focus of more effort than the eastern oyster ( $C$ virginica). Practitioners have been restoring this species along the US Atlantic and Gulf Coasts for decades (Powers et al. 2009; Brown et al. 2014; La Peyre et al. 2014a). Because of the large effort dedicated to promoting the recovery of this species and because of its widespread decline, there is a need for synthesis of the scope and outcomes of restoration conducted across its range. Insights derived from such a review can be used to inform future strategies and to identify where additional investments in restoration may yield the greatest economic and ecological benefits.

Here, we synthesize eastern oyster (hereafter, oyster) restoration approaches, analyze restoration costs and return-oninvestment (ROI), and compare the scales of reef construction to those of historical oyster loss. Although this oyster's distribution extends to Brazil, we focus on restoration along the US Atlantic and Gulf coasts because of the large number of projects initiated on these shorelines and the comparative deficiency of restoration efforts outside the US (Laing et al.2006). We amassed an oyster restoration project dataset by searching Web of Science for peer-reviewed studies using the keywords "oyster reef" and "restoration"; accessing relevant databases (eg the National Oceanic and Atmospheric Administration's Restoration Atlas, The Nature Conservancy's [TNC's] restoration database); and contacting practitioners. We then reviewed the details of each project and retained those that had oysters as a focal species or identified oyster restoration as an added benefit, and were either completed or in progress. We included only those projects that met our standard of "restoration", which we defined as projects in which settlement substrates were deployed or live oysters were planted specifically to enhance or establish reefs and support local oyster population expansion. We excluded fisheries enhancement projects that deployed oyster shell or spat-on-shell with the explicit intent of harvesting this material and the oysters established on it, and also excluded efforts to protect oysters through sanctuary or marine protected area delineation without additional substrate enhancement. Although these strategies are commonly used to manage oysters and support restoration in several US states (eg Maryland, Virginia, North Carolina), they were not the focus of our review. For the 1768 projects included in our database, we recorded the location/water body, year constructed, areal footprint (reported for 1178 projects), substrate type (reported for 1437 projects), and region - Northeast (Maine, New Hampshire, Massachusetts, Rhode Island, Connecticut), MidAtlantic (New York, New Jersey, Delaware), Chesapeake (Maryland, Virginia), Southeast (North Carolina, South Carolina, Georgia, east coast of Florida), and Gulf (west coast of Florida, Alabama, Mississippi, Louisiana, Texas) - as well as data source (see WebTables 1 and 2 for project details).

\section{Temporal and regional restoration trends}

Oyster restoration efforts began in 1964, 1992, and 1993 in the Gulf, Southeast, and Chesapeake, respectively; a total of 5199 ha of settlement substrate have been deployed since, according to the projects included in our database for which size was reported (Figure 1a). Despite a slow start from the 1960s through the 1990s, overall effort has escalated since the 1990s, with an average of 190 ha of reef built each year across the US since 2000, the majority of which has been constructed in the Gulf (3168 ha, representing $61 \%$ of total area reported) and Chesapeake (1828 ha, representing 35\% of total area reported) (Figure 1b). Between 1987 and 2005, practitioners in the Gulf primarily focused on enhancing reef-generated shoreline stabilization, habitat provisioning, and water-quality improvement services (Brown et al. 2014; La Peyre et al. 2014b), and restored an average of 14 ha year $^{-1}$ (with the exception of 1995, when four Alabama projects collectively constructed 1214 ha of reef). Since the mid-2000s, oyster restoration has accelerated further across the Gulf, following passage of The American Recovery and Reinvestment Act (2009) and The RESTORE Act (2012), federal policies that made substantially more funding available for coastal restoration.

As in the Gulf, the pace of oyster restoration in the Chesapeake escalated in the mid-2000s (Figure 1a). These restoration activities, that left substrate in place to rejuvenate and sustain overfished reefs, marked the introduction of a new strategy to the region; since the 1920s, coastal resource managers tasked with supporting commercial fisheries in the Chesapeake had run oyster repletion and broodstock enhancement programs that typically deployed substrate, assuming it would eventually be harvested (Southworth and Mann 1998; Schulte 2017). However, through the implementation of many generally large-scale projects (project size between 1999-2016 averaged 2.85 ha; see WebTable 3 for project size data), practitioners have steadily increased constructed reef area in the Chesapeake over the past 25 years. Oyster restoration has also surged recently in the Southeast, although the scale of reef construction has been considerably smaller in this region than in 
the Gulf and Chesapeake regions (Lenihan and Peterson 1998; Powers et al. 2009; Kingsley-Smith et al. 2012), possibly reflecting a smaller historical reef area and commensurately lower emphasis on oyster rehabilitation relative to other regions. Since 1999, practitioners have been constructing an average of 7 ha of reef annually across the Southeast, much of which has been distributed across numerous small-scale shoreline stabilization projects.

In contrast, our database indicates that only 22 ha and 19 ha of reef have been constructed to date in the Mid-Atlantic and Northeast regions, respectively, (Figure 1b). This reduced activity can be partially attributed to concerns that reestablishing oyster reefs in these heavily populated regions poses a risk to those who may harvest oysters from polluted waters (Martin 2010). Because oyster recruitment is generally low and/or episodic, simply deploying substrate is likely to be insufficient for recovering oyster populations and their ecological functions in these regions (Grizzle and Ward 2016). Instead, positioning substrates with seed oysters on historical reef locations is projected to be a critical, though not welltested (Geraldi et al. 2013), strategy for re-establishing oysters in their northern range (Yozzo et al. 2004). Moreover, uncertainty about historical reef locations impedes identification of suitable restoration sites in many Northeast estuaries (Larsen et al. 2013). Despite these challenges, investment in feasibility studies to identify where restoration may succeed is increasing (eg Grizzle et al. 2011) and public interest in efforts to reestablish reefs across the Northeast and Mid-Atlantic, such as New York's Billion Oyster Project (www.billionoysterproject. org) and the Mass Oyster Project (http://massoyster.org), continues to grow.

\section{Trends in restoration substrates}

A variety of substrates (categorized here into six types; Figure 2) have been used in projects where settlement substrate is thought to limit oyster recovery. Of these, the most commonly used has been oyster shell (both recycled and fossilized), which accounts for 1173 ha of the 3390 ha (34\%) of constructed reef for which we have substrate information. Oyster shell is typically deployed in the form of loose shell, shell bags, shells attached to plastic mats, or spat-on-shell, or through gardening programs in which homeowners grow oysters in cages before they are transplanted onto restored reefs (Figures 3 and 4). Although oyster shell has been moderately used across all regions, projects in the Chesapeake have been particularly reliant on this substrate $(81 \%$ of constructed reef area; Figure 4d). However, rising costs, insufficient quantities, and limited sources of recycled and fossilized shell, as well as shell vulnerability to dislodgement or burial, constrain its application in many locations (La Peyre et al. 2014b). In addition, shell susceptibility to boring sponge infestation and other degradation processes has prompted some practitioners to incorporate other substrates into restoration designs (Powell et al. 2006). In particular, mixed oyster substrates

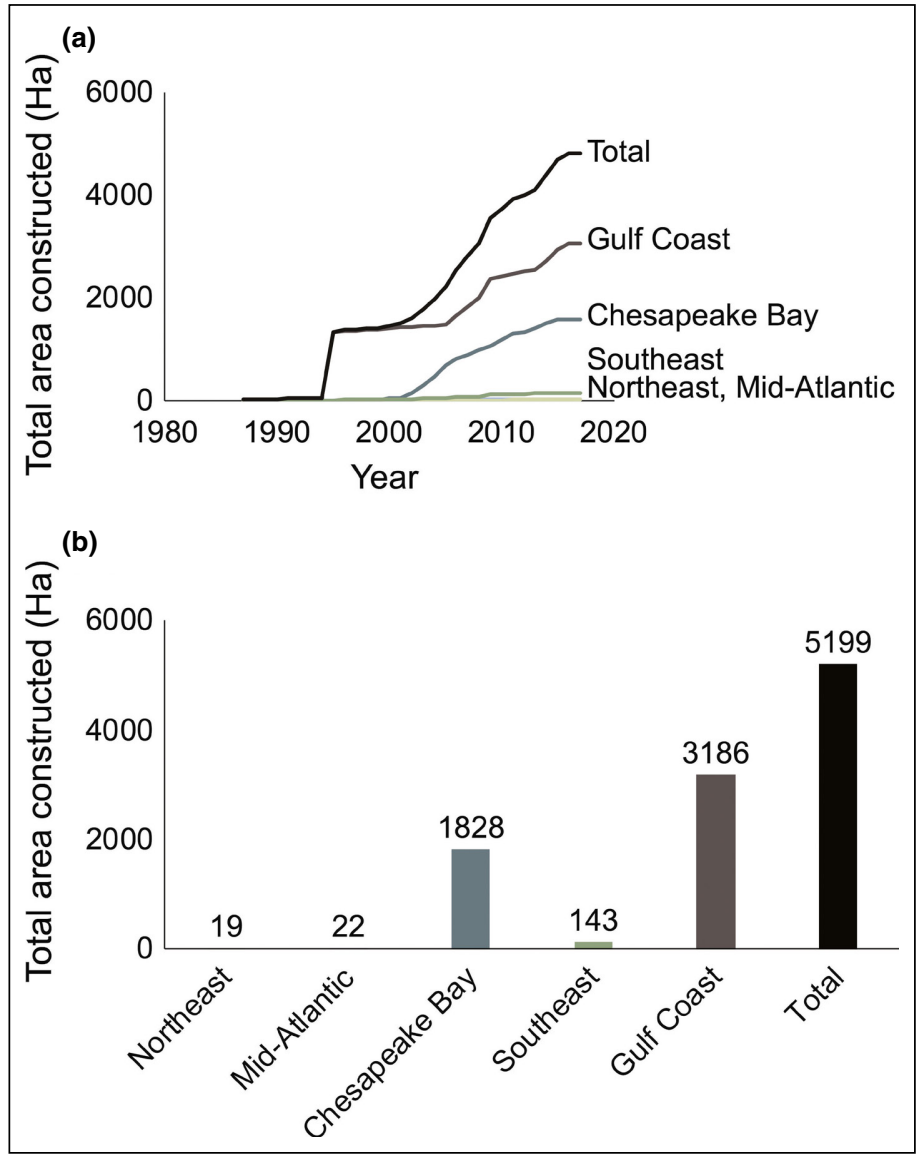

Figure 1. Summary of oyster restoration effort from 1987 to 2017. (a) Cumulative oyster reef area constructed in each region over time, comprising data for 991 projects for which both project area and year constructed were provided. (b) Total constructed reef area by region, showing results from 1178 projects for which project area data were provided.

that combine oyster shell with other types of more readily available shell (eg surf clam, whelk) or more durable materials (eg limestone, granite) have become increasingly popular over the past decade, and currently account for 35\% of the total constructed reef area (Figures $3 a$ and $4 a$ ).

In contrast, concrete and mixed concrete substrates (those combining concrete with other materials, such as limestone or crab traps) are the least commonly used substrates, accounting for only $1.5 \%$ and $2.4 \%$ of the total constructed reef area, respectively (Figures 3 and $4 \mathrm{a}$ ). Concrete-based projects were most frequent in the Southeast $(26 \%$ of constructed reef area: $11 \%$ concrete, $15 \%$ mixed concrete), largely due to widespread deployment of oyster "castles" by the Allied Concrete Company and TNC's South Carolina chapter (Figure 4e). Despite its durability and ability to be cast in a variety of shapes (eg ReefBalls; Figure 2c) or recycled from demolished infrastructure, the higher manufacturing and transportation costs associated with concrete often restrict its use. Another approach that practitioners occasionally adopt is to combine the durability of concrete with the complexity provided by oyster shell, a substrate we refer to here as "mixed", which currently accounts for $2.4 \%$ of total constructed reef area (Figures $3 \mathrm{~b}$ and 4 ). 

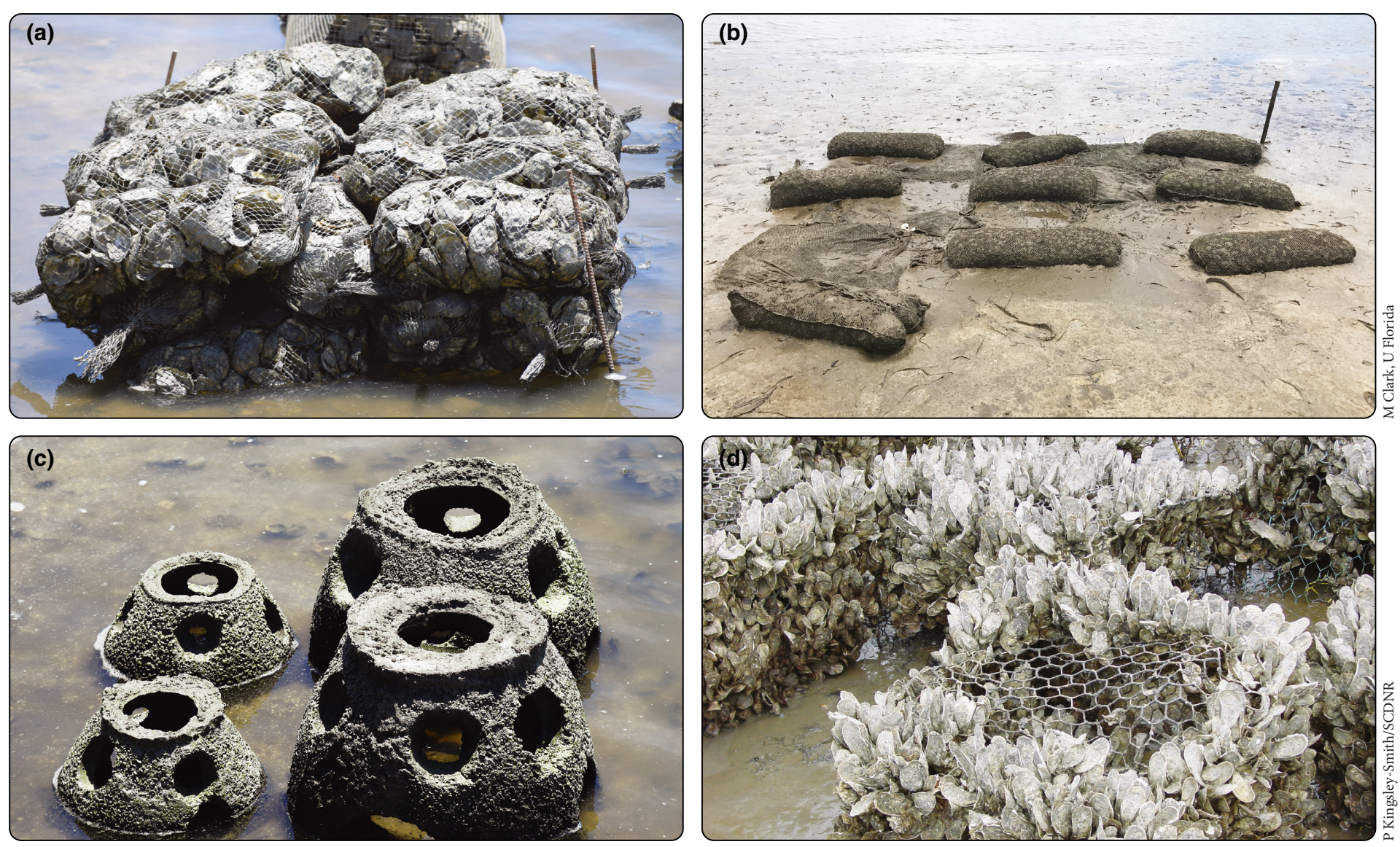

Figure 2. Restoration practitioners have used a variety of oyster restoration substrates, including (a) bagged oyster shell; (b) mixed oyster substrates, such as oyster, scallop, and clam shell bags; (c) concrete structures, such as ReefBalls; and (d) mixed concrete substrates, such as crab traps coated with concrete.

Finally, we classified reefs that did not employ oyster or concrete substrates alone or in combination with other materials as "other" (eg surf clam shell, limestone, granite; Powers et al. 2009; Brown et al. 2014). These materials comprise 9.8\% of total reef area and were most commonly used in the Southeast, where they account for $32 \%$ of the constructed reef area. Due to their low cost and high availability relative to oyster shell and concrete, the use of other substrates more than quadrupled in the years prior to and after 2013 , from 4.8 ha year $^{-1}$ to 24 ha year $^{-1}$.

\section{Restoration costs and benefits}

To establish baseline information about oyster restoration costs, we asked practitioners to share data on projects for which they had records of incurred construction, planning, permitting, labor, and monitoring expenses. Reflecting the vast variability in approaches to establishing reefs, all of these cost categories differed substantially among projects, depending on substrate accessibility, practitioner experience, volunteer participation, project siting (eg subtidal versus intertidal), project goals (eg research and restoration versus restoration alone), and other factors. Since construction defined as the cost of substrate and its on-site placement - was the only cost consistently reported across the 88 projects included in our dataset (eg some projects recruited volunteers while others paid staff, contractors, and/or consultants for labor), we report this value, standardized as the cost of constructing 1 ha of reef in 2016, as a representative measure of restoration costs (see WebTable 4 for project cost details). When interpreting analyses of these data, one must acknowledge both the limited number of projects represented in this database due to difficulties in obtaining cost records and the influence of project designs on areal costs (eg high-relief subtidal reefs often require larger volumes of substrate compared to intertidal reefs, and therefore restoration per hectare of these reefs typically incurs higher costs). Nonetheless, these areal construction cost estimates provide a first-order assessment of the cost-effectiveness of different restoration approaches, and should encourage practitioners and funding agencies to compile and share information on how project funds are allocated to identify cost-saving opportunities (eg Westby et al. 2016).

With these considerations in mind, oyster restoration construction costs were found to range widely, from a low of $\$ 3826$ $\mathrm{ha}^{-1}$ to a high of $\$ 2,180,361 \mathrm{ha}^{-1}$. The average cost of oyster restoration $\left(\$ 299,999 \mathrm{ha}^{-1}\right)$ is four times higher than the average cost of mangrove restoration $\left(\$ 69,387 \mathrm{ha}^{-1}\right)$ and approximately 20 times lower than the average cost of coral reef restoration 
$\left(\$ 5,990,208 \mathrm{ha}^{-1}\right)$ (both values [for mangroves and coral reefs] are from Bayraktarov et al. [2016] and reported in 2016 US\$). On average, concrete was the most expensive $\left(\$ 1,225,579 \mathrm{ha}^{-1}\right)$ and mixed oyster the least expensive $\left(\$ 120,166 \mathrm{ha}^{-1}\right)$ of the substrate types (Table 1).

According to our database, over $\$ 23$ million was invested in these 88 projects. To evaluate the potential yield of these investments, quantification of restoration costs as well as the health of resultant reefs and their production of ecosystem services is needed. Grabowski et al. (2012) estimated ecosystem service benefits derived from oyster reefs to vary between $\$ 5500$ and $\$ 99,000$ $\mathrm{ha}^{-1}$ year $^{-1}$, depending on reef location and which services, at what level, are achieved. Assuming $\$ 10,325 \mathrm{ha}^{-1}$ year $^{-1}$ as the average annual value of ecosystem service benefits derived from restored reefs starting 1 year post-construction, an estimate that includes a 3\% annual discount (Grabowski et al. 2012), we estimated the 14-year ROI (calculated as [\{benefits - costs $\} /$ costs] $\times$ 100) for each project in the database. We use the 14-year interval based on Grabowski et al's (2012) suggestion that oyster restoration costs should be recovered in 2-14 years. However, if restored reefs are left undisturbed, it is possible for them to last 20 years (Powers et al. 2009), meaning they could potentially have higher returns. We then split projects into those with positive ROIs (ie ecosystem service benefits exceeded the project's initial cost after 14 years) and those with negative ROIs (ie project costs were not recaptured through ecosystem service benefits after 14 years). Estimated ROI values ranged from $-93 \%$ to $368 \%$, with one-half of the projects falling into positive and one-half into negative categories (Figure 5).

ROI varied considerably among substrates, with only one of 12 concrete-based reefs yielding a positive ROI compared to 33 of 50 oyster shell reefs. ROI also varied with project size, with $29 \%$ of projects $<0.4$ ha, compared to $75 \%$ of projects $>0.4$ ha, yielding a positive ROI (Figure 5). Feedback from practitioners indicated that the circumstances under which projects were implemented played a critical role in driving this variation. For instance, construction of an oyster-based project in Massachusetts was relatively inexpensive because the site was located close to a shell source, whereas construction of a limestone reef in Matagorda Bay, Texas, was comparatively expensive because heavy equipment and experienced operators were needed to place this substrate on site. Practitioners also noted that the cost of some substrates is rapidly changing: for example, the price per bushel of oyster shell in the Chesapeake rose from $\$ 1.00-\$ 2.00$ in 2010 to $\$ 2.50-\$ 5.00$ in 2017 and the price per bag of shell in the Northeast increased from \$12.50 in 2015 to $\$ 15.00$ in 2017. Collectively, these findings demonstrate that gross differences in the cost-efficiency of oyster restoration can arise depending on a project's substrate, size, and setting, and that restoration costs are evolving. Careful evaluation of these factors will therefore be required to minimize the financial costs of future restoration projects.

Further consideration and quantification of how ecosystem service benefits vary among projects is also essential for assessing the cost-efficiency of oyster restoration. If, for instance, we calculated ROI using the highest annual ecosystem service value derived from restored reefs of $\$ 99,000 \mathrm{ha}^{-1}$ year $^{-1}$ (Grabowski et al.2012), 83 of the 88 projects would have had a positive ROI after 14 years. This simple exercise suggests that implementing more costly projects can be financially justified if the resultant reefs produce high levels of key ecosystem services, as may be the case for concrete-based intertidal reefs that reduce shoreline erosion of valuable coastal properties.

Importantly, progress continues to be made in measuring and predicting the ecosystem service outcomes of oyster restoration. For instance, rigorous monitoring has revealed that deploying spat-on-shell is relatively ineffective for rebuilding vibrant reefs in areas with low natural recruitment in the Southeast (Geraldi et al. 2013) and Gulf (Wallace et al. 2002) 


\section{Region}

(a)

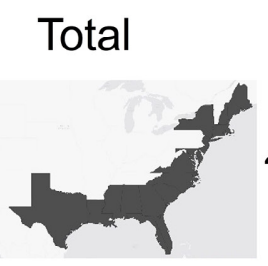

(b)

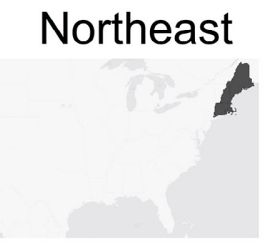

(c)

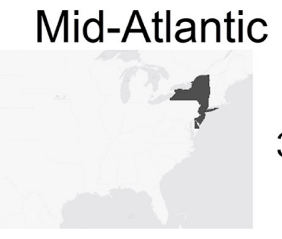

Materials used
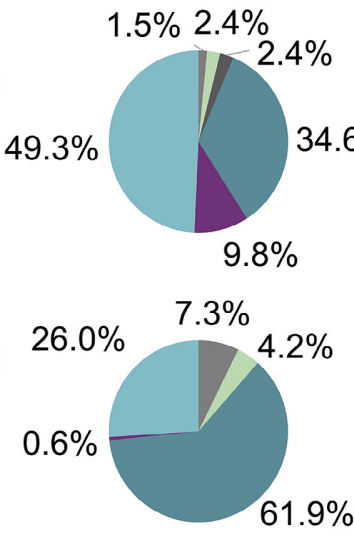

$61.9 \%$

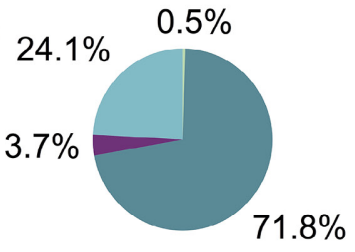

Region

Materials used

(d) Chesapeake

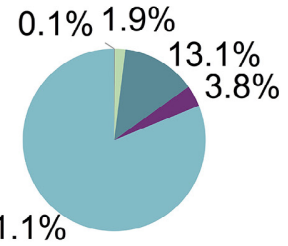

(e)
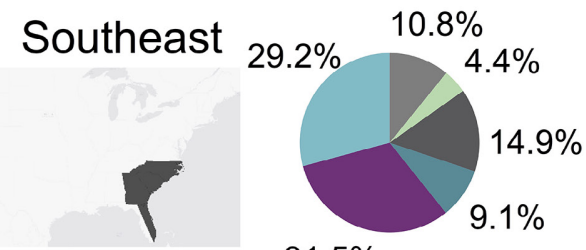

$31.5 \%$

(f)

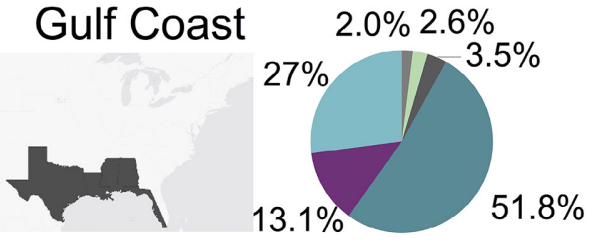

\section{Oyster $\square$ Mixed Oyster $\square$ Concrete $\square$ Mixed Concrete $\square$ Mixed $\square$ Other}

Figure 4. Percent of restoration projects built with oyster, concrete, mixed, or other materials (a) across all sites and (b-f) in each region. Pie charts show data for (a) 1437, (b and c) 24, (d) 594, (e) 301, and (f) 494 projects for which material data were provided.

regions, suggesting that potential oyster-related ecosystem service benefits and ROI are low for projects using this high-cost technique (but see CBP Sustainable Fisheries GIT 2017). Recent meta-analyses are also providing a basis for predicting fish production from oyster reef habitats (Zu Ermgassen et al. 2015); for instance, TNC is incorporating data from these analyses into their Oyster Calculator (http://oceanwealth.org/ tools/oyster-calculator), a tool for scaling restoration projects, which is currently being tested in Florida. These and similar future datasets that use universal metrics to evaluate restored reef health and service provisioning (Baggett et al. 2015; NAS 2017), along with tools enabling managers to forecast planned

Table 1. Number of cost database entries and the average, minimum, and maximum costs per hectare of constructed oyster reef for each material category

\begin{tabular}{lllll} 
& \multirow{2}{*}{$\begin{array}{l}\text { Number of } \\
\text { Material }\end{array}$} & \multicolumn{3}{l}{ Cost per hectare (in US\$) } \\
\cline { 3 - 5 } & 50 & average & minimum & maximum \\
\hline Oyster & 17 & $\$ 137,148$ & $\$ 3826$ & $\$ 411,339$ \\
Mixed oyster & 12 & $\$ 120,166$ & $\$ 4580$ & $\$ 245,028$ \\
\hline Concrete & 2 & $\$ 1,225,579$ & $\$ 22,408$ & $\$ 2,180,361$ \\
\hline Mixed concrete & 2 & $\$ 136,527$ & $\$ 59,046$ & $\$ 214,008$ \\
\hline Mixed & 5 & $\$ 428,483$ & $\$ 67,336$ & $\$ 827,690$ \\
Other & 2 & $\$ 188,622$ & $\$ 184,900$ & $\$ 192,345$ \\
\hline
\end{tabular}

projects' potential success in sustaining ecosystem services, are critical for informing where projects should be placed and what substrates should be used to improve the ROI of future efforts.

Other potentially substantial benefits to oyster restoration not captured in our ROI analyses should also be factored into decisions about when, where, and how projects are implemented. In particular, our estimates do not explicitly account for avoidance costs (those that would be accrued if the restoration activity had not taken place), such as damage to property or loss of shoreline habitats protected by restored reefs. They also do not account for potential multiplicative benefits whereby restored reefs, through their improvement of water quality, stabilization of sediment, facilitation of other species, and production of oyster larvae, improve the health and resilience of surrounding mudflats, beaches, salt marshes, existing oyster reefs, and other coastal habitats. Nor do they capture hard-to-quantify societal benefits, such as those that volunteers derive from connecting with nature while constructing living shorelines or gardening oysters, or educational benefits that students accrue from studying restored reefs. Finally, our analyses do not capture how constructed reefs interact with other natural and anthropogenic factors (eg the evolution of disease-resistant oysters, larvae supplied by sanctuary reefs, freshwater flows) to mediate oyster population dynamics. Because these interactions are complex, it is difficult to discern what percentage of oyster recovery and ecosystem service ben- 


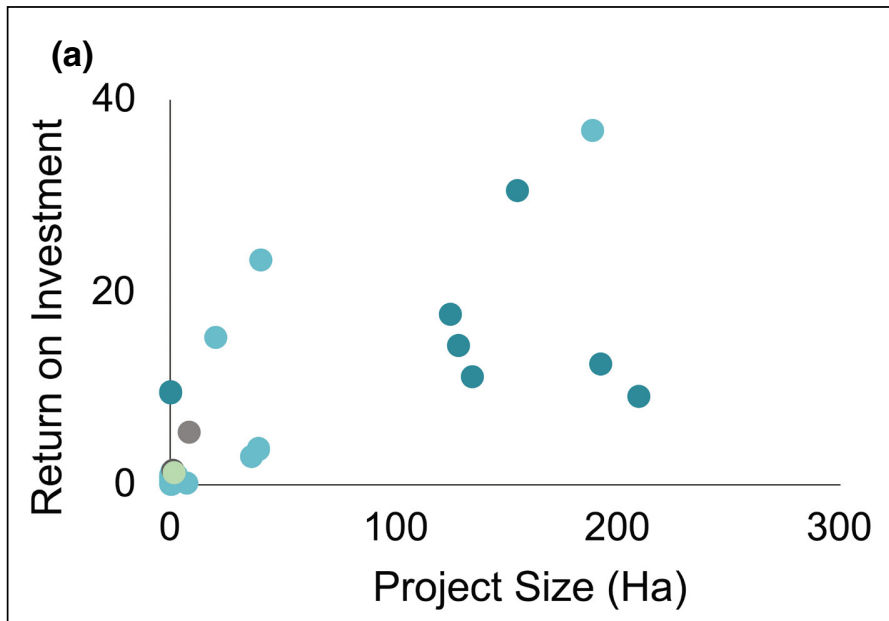

(b)

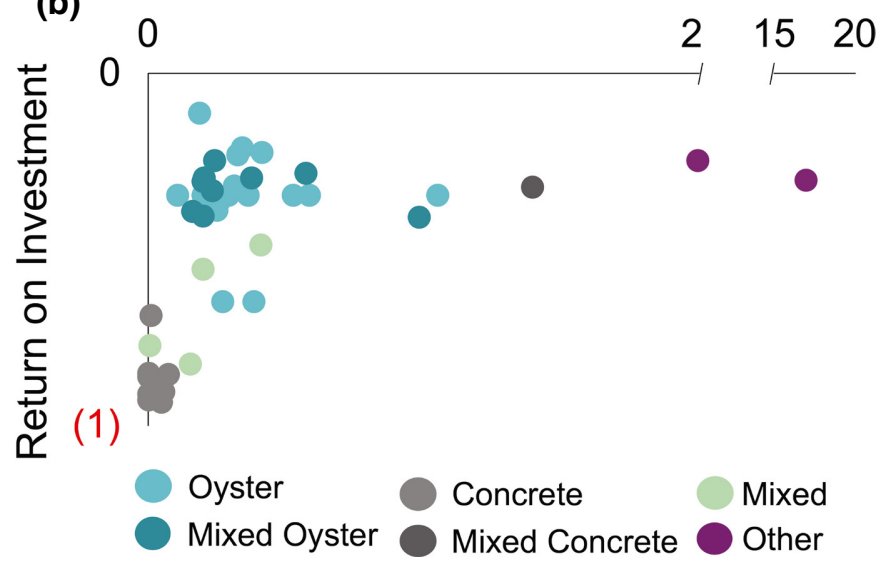

Figure 5. Relationship between return-on-investment (ROI) for 88 oyster reef restoration projects after 14 years and project size for projects with (a) positive and (b) negative Rols. On the y axis, the red "(1)" indicates a negative ROI, meaning that projects lost $100 \%$ of their initial investment.

efits may be due to each factor in cases where oyster populations appear to be increasing, such as in Chesapeake Bay. Further research to measure these additional benefits and to resolve uncertainties about the relative importance of oyster restoration versus fisheries management, sanctuaries, natural processes, and climate change in affecting oyster population dynamics is critical to informing where further investment in restoration may be most effective.

\section{Conclusions}

This synthesis documents an extensive and accelerating effort to restore the eastern oyster. However, when we compared the area of reef constructed to the area of historical reef lost (detailed in $\mathrm{Zu}$ Ermgassen et al. 2012), we discovered that $0.07 \%, 0.9 \%, 3.7 \%, 17.1 \%$, and $4.5 \%$ of degraded reef area has been restored via substrate deployment in the MidAtlantic, Chesapeake, Southeast, and Gulf regions, and the combined total of the Atlantic and Gulf coasts, respectively (see WebTable 5 for details; no historical reef data were available for the Northeast). These percentages would undoubtedly be higher had we included in the calculations restoration projects not captured in our dataset; water bodies where our project database indicates that there has been considerable oyster restoration but for which no historical data were available (eg Lynnhaven River, Virginia, and Tampa Bay, Florida; WebTable 5); areas lacking restoration activities that have been set aside as sanctuaries; and oyster reefs that are now under more sustainable harvest management. Nevertheless, our analyses suggest that practitioners have made greater progress in rebuilding historical reefs in certain water bodies (eg Mobile Bay, Alabama; Pamlico Sound, North Carolina) than in others, and highlight that a tremendous area may still need to be restored for oysters to be rehabilitated at large scales. Given that recovery of even a semblance of historical oyster reef area seems unachievable under our definition of restoration (unless dramatically more funding is made available for reef construction), these findings suggest that marine protected areas and well-managed harvest reefs must be incorporated into oyster management plans. Furthermore, because a lack of suitable substrate is by no means the only reason for oyster decline, strategies to rehabilitate this coastal habitat must also consider the role of other environmental factors (eg disease, salinity, water quality) in mediating oyster population dynamics.

Whether the societal goal of restoration is to fully recover historical habitat that has been lost or simply to re-establish enough habitat to generate desired ecosystem services, our analyses indicate that there is a long way to go to achieving either endpoint for oyster reefs. Our finding that the ROI for restoration tends to increase with project size (Figure 5) suggests that there is critical need for novel, cost-effective strategies that allow restoration of much larger areas. In particular, innovations in substrate types and/or how they are sourced (eg recycled concrete, mass-manufactured textured substrates) and placed on site are essential for reducing construction costs. Similarly, strategic approaches for minimizing labor costs (eg homeowner gardening and other volunteer programs) can also trim project budgets. In reviewing the literature, we found widespread evidence that site characteristics, including elevation and access to adequate larval supply, also greatly influence restoration success (Schulte et al. 2009; Grizzle and Ward 2016; Colden et al. 2017). Consequently, developing and utilizing longer term, larger scale, and standardized water-quality and oyster recruitment monitoring datasets - to identify sites where restoration activities are likely to stimulate the recovery of self-sustaining, productive oyster reefs - is an essential first step in designing projects that yield positive ROIs. Such advancements in techniques and site selection are essential for making more effective use of funds allocated to the restoration of this degraded coastal habitat.

\section{Acknowledgements}

Funding was provided by the University of Florida Graduate Student Fellowship to ABH, the NOAA NERR Science 
Collaborative grant awarded to CA and RG, and NSF DEB 1546638 and NSF CAREER 1652628 award to CA. We thank B DeAngelis for contributions and help.

\section{References}

Alleway HK and Connell SD. 2015. Loss of an ecological baseline through the eradication of oyster reefs from coastal ecosystems and human memory. Conserv Biol 29: 795-804.

Baggett LP, Powers SP, Brumbaugh RD, et al. 2015. Guidelines for evaluating performance of oyster habitat restoration. Restor Ecol 23: 737-45.

Bayraktarov E, Saunders MI, Abdullah S, et al. 2016. The cost and feasibility of marine coastal restoration. Ecol Appl 26: 1055-74.

Beck MW, Brumbaugh RD, Airoldi L, et al. 2011. Oyster reefs at risk and recommendations for conservation, restoration, and management. BioScience 61: 107-16.

Berry D. 2008. Maryland's skipjacks. Mount Pleasant, SC: Arcadia Publishing.

Brown LA, Furlong JN, Brown KM, and La Peyre MK. 2014. Oyster reef restoration in the northern Gulf of Mexico: effect of artificial substrate and age on nekton and benthic macroinvertebrate assemblage use. Restor Ecol 22: 214-22.

CBP Sustainable Fisheries GIT (Chesapeake Bay Program's Sustainable Fisheries Goal Implementation Team). 2017.2016 oyster reef monitoring report. Analysis of data from large-scale sanctuary oyster restoration projects in Maryland. Annapolis, MD: NOAA Chesapeake Bay Office. https://chesapeakebay.noaa.gov/ images/stories/pdf/2016oysterreefmonitoringreport.pdf. Viewed 1 May 2018.

Coen LD, Brumbaugh RD, Bushek D, et al. 2007. Ecosystem services related to oyster restoration. Mar Ecol-Prog Ser 341: 303-07.

Colden AM, Latour RJ, and Lipcius RN. 2017. Reef height drives threshold dynamics of restored oyster reefs. Mar Ecol-Prog Ser 582: 1-13.

Diederich S, Nehls G, van Beusekom JEE, and Reise K. 2005. Introduced Pacific oysters (Crassostrea gigas) in the northern Wadden Sea: invasion accelerated by warm summers? Helgoland Mar Res 59: 97-106.

Dinnel PA, Peabody B, and Peter-Contesse T. 2009. Rebuilding Olympia oysters, Ostrea lurida Carpenter 1864, in Fidalgo Bay, Washington. J Shellfish Res 28: 79-85.

FAO (Food and Agricultural Organization). 2014. The state of world fisheries and aquaculture: opportunities and challenges. Rome, Italy: FAO.

Geraldi NR, Simpson M, Fegley SR, et al. 2013. Addition of juvenile oysters fails to enhance oyster reef development in Pamlico Sound. Mar Ecol-Prog Ser 480: 119-29.

Grabowski JH, Hughes AR, Kimbro DL, and Dolan MA. 2005. How habitat setting influences restored oyster reef communities. Ecology 86: 1926-35.

Grabowski JH, Brumbaugh RD, Conrad RF, et al. 2012. Economic valuation of ecosystem services provided by oyster reefs. BioScience 62: 900-09.

Grizzle RE and Ward K. 2016. Assessment of recent eastern oyster (Crassostrea virginica) reef restoration projects in the Great Bay
Estuary, New Hampshire: planning for the future. Durham, NH: Piscataqua Region Estuaries Partnership.

Grizzle RE, Ward K, Lodge J, et al. 2011. Oyster Restoration Research Project (ORRP) technical report. New York, NY: Hudson River Foundation.

Halpern BS, Walbridge S, Selkoe KA, et al. 2008. A global map of human impact on marine ecosystems. Science 319: 948-52.

Jackson JBC. 2008. Ecological extinction and evolution in the brave new ocean. P Natl Acad Sci USA 105: 11458-65.

Kingsley-Smith PR, Joyce RE, Arnott SA, et al. 2012. Habitat use of intertidal eastern oyster (Crassostrea virginica) reefs by nekton in South Carolina estuaries. J Shellfish Res 31: 1009-21.

Kirby MX. 2004. Fishing down the coast: historical expansion and collapse of oyster fisheries along continental margins. P Natl Acad Sci USA 101: 13096-99.

Kuijper WJ and Turner H. 1992. Diet of a Roman centurion at Alphen aan den Rijn, The Netherlands, in the first century AD. Rev Palaeobot Palyno 73: 187-204.

La Peyre MK, Humphries AT, Casas SM, and La Peyre JF. 2014a. Temporal variation in development of ecosystem services from oyster reef restoration. Ecol Eng 63: 34-44.

La Peyre M, Furlong J, Brown LA, et al. 2014b. Oyster reef restoration in the northern Gulf of Mexico: extent, methods and outcomes. Ocean Coast Manage 89: 20-28.

Laing I, Walker P, and Areal F. 2006. Return of the native - is European oyster (Ostrea edulis) stock restoration in the UK feasible? Aquat Living Resour 19: 283-87.

Larsen PF, Wilson KA, and Morse D. 2013. Observations on the expansion of a relict population of Eastern oysters (Crassostrea virginica) in a Maine estuary: implications for climate change and restoration. Northeast Nat 20: 28-33.

Lenihan HS and Peterson CH. 1998. How habitat degradation through fishery disturbance enhances impacts of hypoxia on oyster reefs. Ecol Appl 8: 128-40.

Lotze HK, Reise K, Worm B, et al. 2005. Human transformations of the Wadden Sea ecosystem through time: a synthesis. Helgoland Mar Res 59: 84-95.

Lotze HK, Lenihan HS, Bourque BJ, et al. 2006. Depletion, degradation, and recovery potential of estuaries and coastal seas. Science 312: 1806-09.

MacKenzie Jr CL. 1996. History of oystering in the United States and Canada featuring the eight greatest oyster estuaries. Mar Fish Rev 58: $1-78$.

Martin R. 2010. Commissioner aims to protect public health and shellfish industry. Trenton, NJ: New Jersey Department of Environmental Protection. www.nj.gov/dep/newsrel/2010/10_0053.htm. Viewed 1 May 2018.

McGraw KA. 2009. The Olympia oyster, Ostrea lurida Carpenter 1864 along the west coast of North America. J Shellfish Res 28: 5-10.

NAS (National Academies of Sciences). 2017. Effective monitoring to evaluate ecological restoration in the Gulf of Mexico. Washington, DC: The National Academies Press.

NMFS (National Marine Fisheries Service). 2015. Annual commercial landing statistics. Silver Spring, MD: NOAA. www.st.nmfs.noaa. gov/commercial-fisheries/commercial-landings/annual-landings/ index. Viewed 21 Jul 2017. 
Powell EN, Kraeuter JN, and Ashton-Alcox KA. 2006. How long does oyster shell last on an oyster reef? Estuar Coast Shelf $S$ 69: 531-42.

Powers SP, Peterson CH, Grabowski JH, and Lenihan HS. 2009. Success of constructed oyster reefs in no-harvest sanctuaries: implications for restoration. Mar Ecol-Prog Ser 389: 159-70.

Rick TC, Reeder-Myers LA, Cox CJ, et al. 2014. Shell middens, cultural chronologies, and coastal settlement on the Rhode River subestuary of Chesapeake Bay, Maryland, USA. Geoarchaeology 29: 371-88.

Schulte DM. 2017. History of the Virginia oyster fishery, Chesapeake Bay, USA. Front Mar Sci 4: 127.

Schulte DM, Burke RP, and Lipcius RN. 2009. Unprecedented restoration of a native oyster metapopulation. Science 325: 1124-28.

Smyth D, Roberts D, and Browne L. 2009. Impacts of unregulated harvesting on a recovering stock of native oysters (Ostrea edulis). Mar Pollut Bull 58: 916-22.

Southworth MJ and Mann R. 1998. Oyster reef broodstock enhancement in the Great Wicomico River, Virginia. J Shellfish Res 17: 1101-14.

UNEP (United Nations Environment Programme). 2006. Marine and coastal ecosystems and human well-being: synthesis. Nairobi, Kenya: UNEP.

Wallace R, Rikard F, and Howe J. 2002. Optimum size for planting hatchery produced oyster seed: final technical report. Ocean Springs, MS: Mississippi-Alabama Sea Grant Consortium.
Westby SR, Bruce D, and Slacum W, et al. 2016. 2015 oyster restoration implementation update. Restoration progress in Harris Creek, Little Choptank River, and Tred Avon River combined. Annapolis, MD: NOAA Chesapeake Bay Office.

White JM, Buhle ER, Ruesink JL, and Trimble AC. 2009. Evaluation of Olympia oyster (Ostrea lurida Carpenter 1864) status and restoration techniques in Puget Sound, Washington, United States. J Shellfish Res 28: 107-12.

Worm B, Barbier EB, Beaumont N, et al. 2006. Impacts of biodiversity loss on ocean ecosystem services. Science 314: 787-90.

Yozzo DJ, Wilber P, and Will RJ. 2004. Beneficial use of dredged material for habitat creation, enhancement, and restoration in New York-New Jersey Harbor. J Environ Manage 73: 39-52.

Zu Ermgassen PSE, Spalding MD, Blake B, et al. 2012. Historical ecology with real numbers: past and present extent and biomass of an imperiled estuarine habitat. P Roy Soc B-Biol Sci 279: 3393-400.

Zu Ermgassen PSE, Grabowski JH, Gair JR, and Powers SP. 2015. Quantifying fish and mobile invertebrate production from a threatened nursery habitat. J Appl Ecol 53: 596-606.

\section{Supporting Information}

Additional, web-only material may be found in the online version of this article at http://onlinelibrary.wiley.com/ doi/10.1002/fee.1935/suppinfo

\section{FrontiersEcoPics}

\section{Not just corals - sponges are bleaching too!}

While coral bleaching is a well-known phenomenon, incidences of sponge bleaching might not be on the radar for many who are documenting coral reef vulnerability. Like corals, sponges also face environmental stressors that can compromise their health. Following exposure to stress events, sponges can lose cells, leaving a bare skeleton. Some species live in symbiosis with photosynthetic organisms, and the loss of these communities as a result of environmental stress can lead to sponges "bleaching", in a process similar to that seen in corals.

Reports of sponge bleaching are limited to a few species, including Giant Barrel Sponges (Xestospongia spp) and encrusting bio-eroding
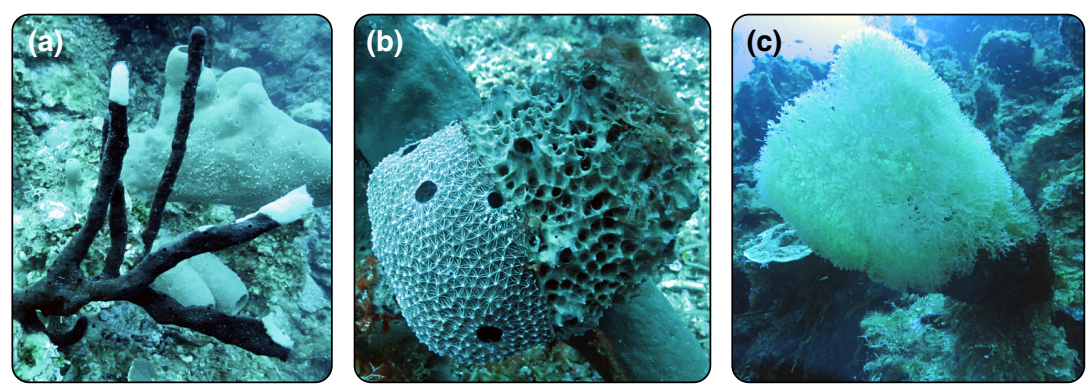

sponges (Cliona spp). However, singular events of multiple species of sponges within reefs showing whole or partial bleaching, as well as disease, cell loss, and exposed skeletons, are not routinely reported.

Several individuals from five species of bleached, diseased, or necrotic sponges were found over a reef track of approximately $100 \mathrm{~m}$, at depths of 15-22 m, at Bloody Bay Wall, Little Cayman Island. These were (a) Amphimedon compressa, (b) Ircinia felix, (c) Mycale laxissima, (d) Xestospongia muta, and (e) Agelas tubulata. The cause of this sponge bleaching episode is unknown. While increased temperature is often an important factor in coral bleaching there were no temperature anomalies observed immediately prior to the observation. Incidences of bleaching and disease for taxa other than corals have immense value in assessments of overall coral reef health, and highlight the critical need for these types of observations to be recorded and quantified.

Steve Whalan Central Caribbean Marine Institute, Cayman Islands doi:10.1002/fee.1957
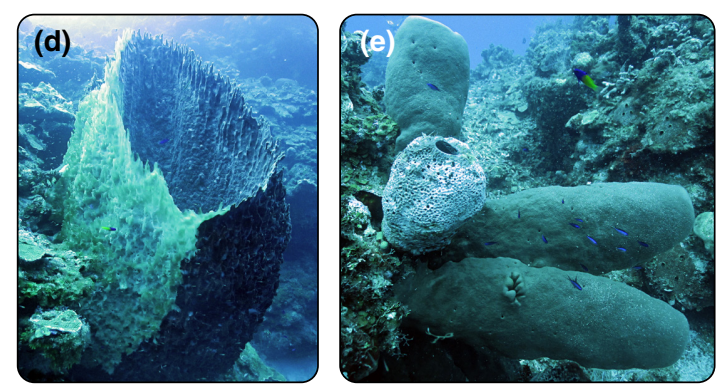